Section Editor

Mitchell S.V. Elkind, MD, MS

Sunil A. Sheth, MD Alan H. Yee, DO

Correspondence to Dr. Yee:

Alan.yee@ucsf.edu

Mystery Case:

\title{
An unexpected complication of IV thrombolysis for acute ischemic stroke
}

Figure Left middle cerebral artery occlusion and expanding retro-orbital hematoma

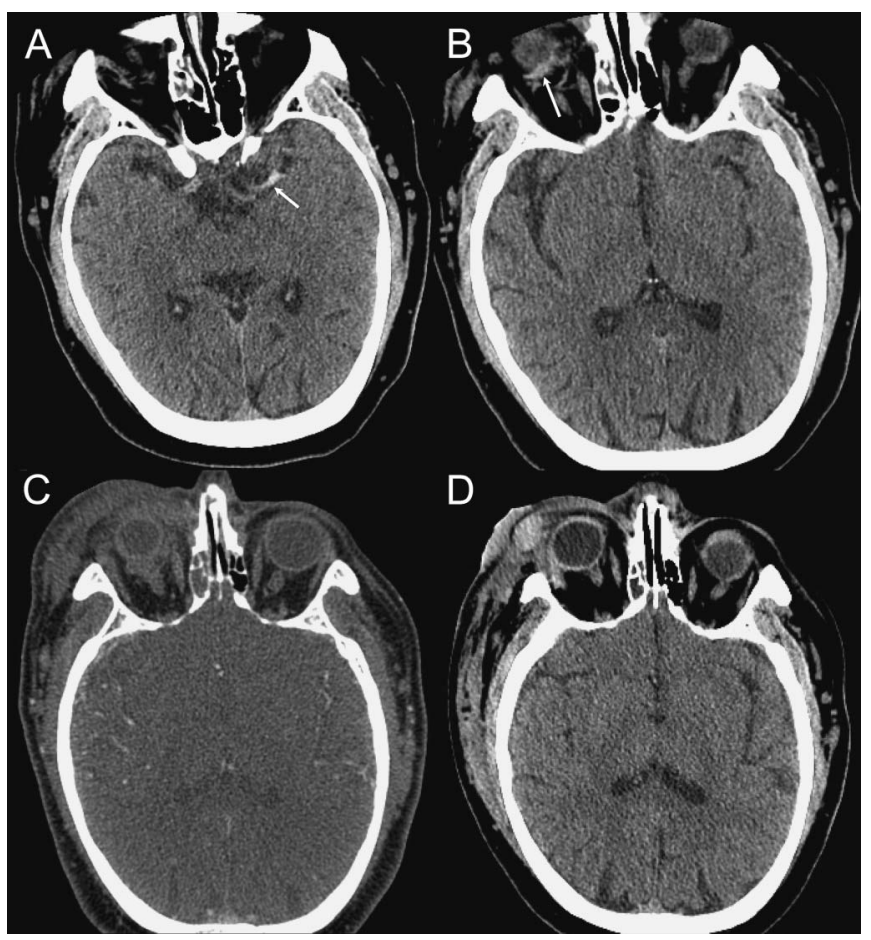

(A) Initial noncontrast head CT with hyperdense abnormality within the left middle cerebral artery (arrow). (B) Right retroorbital hematoma (arrow). (C) CT angiography after IV recombinant tissue plasminogen activator administration demonstrates retro-orbital hematoma expansion, progressive periorbital edema, and worsening proptosis. (D) Noncontrast head CT 24 hours after thrombolysis demonstrates interval improvement of the retro-orbital hematoma as well as minimal cerebral ischemic changes.

A 46-year-old man with psoriasis and morbid obesity developed acute aphasia and right hemiplegia. As a result of his weakness, he had fallen and struck his right eye on a desk. His presenting examination demonstrated right periorbital ecchymosis without accompanying ptosis, expressive aphasia, left gaze deviation with corresponding hemianopsia, and dense right hemiplegia, summating an NIH Stroke Scale score of 13.

Questions for consideration:

1. What is the finding(s) on these noncontrast CT images?

2. Should this patient be treated with IV tissue plasminogen activator $(\mathrm{tPA})$ ?
The patient was noted to have a hyperdense abnormality within the proximal left middle cerebral artery on initial noncontrast imaging concerning for acute thrombosis (figure, A). He received IV tPA within 2 hours from symptom onset, and noticed significant neurologic improvement within 20 minutes of initiation of therapy.

Approximately 45 minutes after initiation of IV recombinant tPA, the patient developed increasing monocular blindness and complete closure of the right eye from rapidly progressive periorbital edema and ecchymosis. Re-examination of cranial imaging at presentation and following IV thrombolysis confirmed an enlarging retro-orbital hematoma (figure, $\mathrm{B}$ and $\mathrm{C}$ ). An 
emergent lateral canthotomy was performed to decompress the optic nerve and within 3 days of orbital decompression and ischemic stroke treatment, he had near complete visual and neurologic recovery. Followup cranial and orbital imaging performed 24 hours after canthotomy demonstrated resolution of the retroorbital hematoma (figure, D).

The small retro-orbital hematoma present on the initial imaging had been overlooked during the screening and decision-making process to administer thrombolytic therapy. Although the patient recovered without significant cerebral or visual impairment as a result of immediate intervention, it is unclear whether IV recombinant tPA should be withheld in this context. IV thrombolysis for ischemic stroke has been performed after vitrectomy without complication, ${ }^{1}$ but the presence of intraocular hemorrhage has led to withholding treatment in other cases. $^{2}$

IV tPA has consistently been shown to be safe and efficacious following ischemic stroke. ${ }^{3}$ However, thrombolytic treatment should proceed with caution even in the setting of minor trauma, and this case highlights the importance of careful inspection and vigilance for unanticipated complications.

\section{AUTHOR CONTRIBUTIONS}

Dr. Sheth and Dr. Yee were involved in the care of the patient, study design, data analysis, and preparation of the manuscript.

\section{STUDY FUNDING}

No targeted funding reported.

\section{DISCLOSURE}

The authors report no disclosures relevant to the manuscript. Go to Neurology.org for full disclosures.

\section{REFERENCES}

1. Pérez-Díaz H, Carballo M, Gil-Peralta A. Intravenous thrombolysis for acute ischemic stroke after vitrectomy for retinal detachment. Stroke 2007;38:e60.
2. Ahmad A, Teoh HL, Sharma VK. Would you perform thrombolysis in this acute ischemic stroke patient? Arch Neurol 2009;66:410-411.

3. The National Institute of Neurological Disorders and Stroke rt-PA Stroke Study Group. Tissue plasminogen activator for acute ischemic stroke. N Engl J Med 1995;333:1581-1587.

MYSTERY CASE RESPONSES The Mystery Case series was initiated by the Neurology ${ }^{\circledR}$ Resident \& Fellow Section to develop the clinical reasoning skills of trainees. Residency programs, medical student preceptors, and individuals were invited to use this Mystery Case as an educational tool. Responses were solicited through a group e-mail sent to the American Academy of Neurology Consortium of Neurology Residents and Fellows and through social media. All of the responses that we received came from individuals rather than groups. Eighty-seven percent of respondents correctly identified the hyperdense left middle cerebral artery sign on the patient's CT scan, and 33\% of respondents identified the right retro-orbital hematoma. Regarding management, $77 \%$ of respondents stated that the patient should receive IV tPA, while the other $23 \%$ stated that IV tPA should be withheld because of the hematoma. The most complete answer came from Dr. Anil Neelakantan who recognized that IV tPA could lead to expansion of the retro-orbital hematoma and compression of the optic nerve, both of which occurred in this case. Fortunately, the patient had a near-complete recovery of vision after an emergent canthotomy.

As the authors have acknowledged in their case report, the appropriate treatment decision in this situation is not clear-cut. Nevertheless, it is important to carefully review neuroimaging in the setting of stroke following head trauma so that hemorrhagic complications such as the one in this case can be anticipated.

Andrew Schepmyer, BHSc (Hons), MD

Department of Neurology, University of British Columbia, Vancouver, Canada. 


\section{Neurology}

\section{Mystery Case: An unexpected complication of IV thrombolysis for acute ischemic stroke}

Sunil A. Sheth and Alan H. Yee

Neurology 2013;81;e42-e43

DOI 10.1212/WNL.0b013e3182a08d7f

\section{This information is current as of August 12, 2013}

\section{Updated Information \& Services}

\section{References}

Subspecialty Collections

\section{Permissions \& Licensing}

\section{Reprints}

including high resolution figures, can be found at: http://n.neurology.org/content/81/7/e42.full

This article cites 3 articles, 1 of which you can access for free at: http://n.neurology.org/content/81/7/e42.full\#ref-list-1

This article, along with others on similar topics, appears in the following collection(s):

All Cerebrovascular disease/Stroke

http://n.neurology.org/cgi/collection/all_cerebrovascular_disease_strok

Optic nerve

http://n.neurology.org/cgi/collection/optic_nerve

Orbit

http://n.neurology.org/cgi/collection/orbit

Stroke in young adults

http://n.neurology.org/cgi/collection/stroke_in_young_adults

Visual loss

http://n.neurology.org/cgi/collection/visual_loss

Information about reproducing this article in parts (figures,tables) or in its entirety can be found online at:

http://www.neurology.org/about/about_the_journal\#permissions

Information about ordering reprints can be found online:

http://n.neurology.org/subscribers/advertise

Neurology ${ }^{\circledR}$ is the official journal of the American Academy of Neurology. Published continuously since 1951, it is now a weekly with 48 issues per year. Copyright @ 2013 American Academy of Neurology. All rights reserved. Print ISSN: 0028-3878. Online ISSN: 1526-632X.

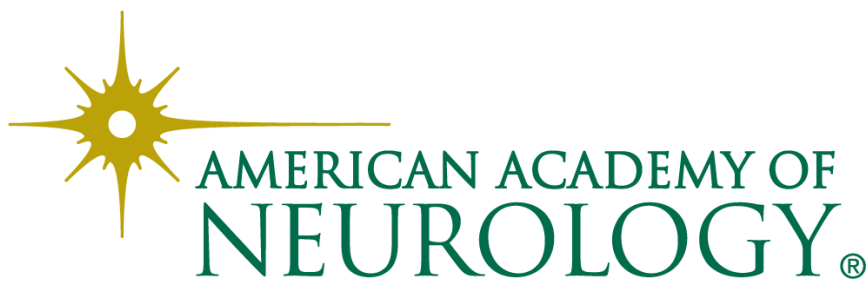

